\title{
Journal of Hazardous Substance Research
}

$1-1-1998$

\section{Ability of Immobilized Cyanobacteria to Remove Metal Ions From Solution and Demonstration of the Presence of Metallothionein Genes in Various Strains}

\author{
J. L. Gardea-Torresdey \\ University of Texas at El Paso \\ J. L. Arenas \\ University of Texas at El Paso \\ N. M. C. Francisco \\ University of Texas at El Paso
}

See next page for additional authors

Follow this and additional works at: https://newprairiepress.org/jhsr

\section{Recommended Citation}

Gardea-Torresdey, J. L.; Arenas, J. L.; Francisco, N. M. C.; Tiemann, K. J.; and Webb, R. (1998) "Ability of Immobilized Cyanobacteria to Remove Metal Ions From Solution and Demonstration of the Presence of Metallothionein Genes in Various Strains," Journal of Hazardous Substance Research: Vol. 1.

https://doi.org/10.4148/1090-7025.1001

This Article is brought to you for free and open access by New Prairie Press. It has been accepted for inclusion in Journal of Hazardous Substance Research by an authorized administrator of New Prairie Press. For more information, please contact cads@k-state.edu. 


\section{Ability of Immobilized Cyanobacteria to Remove Metal Ions From Solution and Demonstration of the Presence of Metallothionein Genes in Various Strains}

\section{Authors}

J. L. Gardea-Torresdey, J. L. Arenas, N. M. C. Francisco, K. J. Tiemann, and R. Webb 


\title{
ABILITY OF IMMOBILIZED CYANOBACTERIA TO REMOVE METAL IONS FROM SOLUTION AND DEMONSTRATION OF THE PRESENCE OF METALLOTHIONEIN GENES IN VARIOUS STRAINS
}

\author{
J. L. Gardea-Torresdey ${ }^{\mathrm{a}}$, J. L. Arenas ${ }^{\mathrm{b}}$, N.M.C. Francisco ${ }^{\mathrm{b}}$, K. J. Tiemann ${ }^{\mathrm{a}}$, R. Webb ${ }^{\mathrm{b}}$ \\ ${ }^{a}$ Department of Chemistry and ${ }^{b}$ Department of Biological Sciences, The University of Texas at \\ El Paso, El Paso, TX, 79968, Phone 915-747-5359, FAX: 915-747-5748.
}

\begin{abstract}
Synechococcus sp. PCC 7942 has the ability to grow in mass quantity under ideal conditions; such an ability provides usable biomass at a minimal effort. Using lyophilized biomass grown under normal conditions, Synechococcus was tested for its potential to bind metal ions from solution. Batch experiments have determined the optimum binding $\mathrm{pH}$, time dependency, and metal binding capacities for copper(II), lead(II), nickel(II), cadmium(II), chromium(III), and chromium(VI), along with desorption of the metal bound. The biomass studied showed an affinity for five of the metal ions, with an optimum binding at $\mathrm{pH}$ 5. Time dependency studies showed that this cyanobacterium had rapid binding, while capacity experiments showed this cyanobacterial strain to bind $11.3 \mathrm{mg}$ of copper(II) per gram of biomass, $30.4 \mathrm{mg}$ of lead(II) per gram of biomass, $3.2 \mathrm{mg}$ of nickel(II) per gram of biomass, $7.2 \mathrm{mg}$ of cadmium (II) per gram of biomass, and $5.4 \mathrm{mg}$ of chromium (III) per gram of biomass. More than $98 \%$ of copper(II), lead(II), and nickel(II) metal ions were recovered, while over $50 \%$ of cadmium(II) and chromium(III) were recovered when treated with $0.1 \mathrm{M} \mathrm{HCl}$. The biomass was immobilized in a silica polymer and tested for its binding ability under flow conditions. Using $0.1 \mathrm{mM}$ concentrations of the previously indicated metals, individual experimental results showed an average of $143 \mathrm{mg} / \mathrm{L}$ copper(II), $1456 \mathrm{mg} / \mathrm{L}$ lead(II), $142 \mathrm{mg} / \mathrm{L}$ nickel(II), and $529 \mathrm{mg} / \mathrm{L}$ cadmium(II) bound by the immobilized biomass. Treatment with $0.2 \mathrm{M} \mathrm{HCl}$ resulted in nearly $100 \%$ recovery for both copper(II) and lead(II) from the column, $79 \%$ recovery of cadmium(II), while recovery for nickel(II) was $42 \%$. Experiments were conducted to determine if many cycles of metal bindingstripping by the immobilized biomass were possible. Further, attempts were made to demonstrate the presence of metallothioneins in various strains of cyanobacteria which may serve as defense mechanisms against metal ion toxicity. Such proteins may be used to develop engineered strains of cyanobacteria with increased metal ion binding ability. Synechococcus can eventually be used as a source for a novel approach in using biosystems to remediate contaminants from solution and making those contaminants available to industry through an environmentally friendly biofiltration system.
\end{abstract}

Key words: Synechococcus, cyanobacteria, heavy metal binding, bioremediation, metal recovery

\section{INTRODUCTION}

Environmental pollution and contamination have become a key focus of concern. Changes in technology and manufacturing practices are providing relief to these problems. However, some of the present methods of environmental cleanup result in the production of harmful by-products. Environmentally friendly processes need to be developed to clean up the environment without creating harmful waste products. 
Cyanobacteria (also known as blue-green algae) are the largest and most diverse group of photosynthetic prokaryotes. Their habitats vary from fresh and marine water to terrestrial environments. They are oxygen-evolving organisms that respond to stress conditions such as light deprivation (Borbely et al., 1990.). These cells have developed natural methods of responding to metals such as copper, lead, and cadmium through passive accumulation in cells and through surface binding to various functional groups. They have also been found to remove harmful metals from the environment. For example, Spirulina platensis, a cyanobacterium, was shown to contain detectable levels of mercury and lead when grown under contaminated conditions (Slotton et al.,1989), implying that this cyanobacterium was taking up the toxic metal ions from its environment. Further studies confirmed that this cyanobacterium both adsorbs and takes up metal ions (Bender et al.,1994). Reports also indicate that carboxyl groups on algal cell biomass are responsible for binding to various ions (Gardea-Torresdey et al.,1990). Live algae possess intracellular polyphosphates which participate in metal sequestration, as well as algal extracellular polysaccharides that serve to chelate or bind metal ions (Zhang and Majidi,1994; Kaplan et al.,1987; Van Eykelenburg,1978). Strains of Synechocystis spp. have been shown to develop a thickened calyx when exposed to copper-stressed growth conditions (Gardea-Torresdey et al.,1996a). Synechococcus sp. PCC 7942 was found to possess a copper-transporting P-type ATPase in the thylakoid membrane (Bonilla et al.,1995). Synechococcus cedrorum 1191 was shown to be tolerant to heavy metals and pesticides (Gothalwal and Bisen,1993). Other investigators have studied the biosorption of heavy metals by algal biomass (Volesky and Holan, 1994; Volesky and Holan, 1995; Volesky and Schiewer, 1997). Such findings show the possibility of manipulating or overexpressing existing resistance mechanisms and the use of such organisms to remove harmful metals from the environment.

An important resistance mechanism may be the production of metallothioneins. Metallothioneins are low-molecular weight proteins or polypeptides $(6,000-8,000 \mathrm{amu})$ which bind metal ions in metal-thiolate clusters. These polypeptides are abundant in cysteine residues (cys) and often possess a characteristic pattern of sulfur containing amino acids (Turner and Robinson,1995). They are commonly found in association with essential metal ions such as zinc and copper but have also been shown to bind toxic metals like cadmium, mercury, and lead. Their metal binding properties are mediated via the abundant cysteine residues and their characteristic 
organization into -Cys-Cys-, -Cys-X-Cys-, or -Cys-X-X-Cys- sequences (x corresponds to any other amino acid in the protein sequence). Synthesis of metallothioneins has been shown to be prompted by elevated concentrations of some metals (Turner and Robinson, 1995).

Metallothioneins can be characterized into three specific classes: class I contains most animal metallothioneins; class II consists of metallothioneins whose cysteine locations in the polypeptide are distantly related to those found in archetypal equine renal metallothioneins; and class III metallothioneins are characterized by atypical non-translationally synthesized metal-thiolate polypeptides. Cyanobacterial metallothioneins belong to class II. They possess approximately 56 amino acids including nine cysteine residues. This number of cysteine residues is less than the 20 cysteine residues out of 60 amino acids for the animal class I metallothioneins and 12 cysteine residues out of 75 amino acids for plant class I metallothioneins (Silver and Ji,1994).

Until now, a complete study of the uptake of heavy metal ions by the inactivated biomass of cyanobacteria (under batch and flow conditions), specifically Synechococcus spp., has not been fully performed. In addition, metallothionein expression by various strains of cyanobacteria has yet to be investigated.

The purpose of our investigation was to study the ability of Synechococcus sp. PCC 7942 to uptake copper(II), lead(II), cadmium(II), nickel(II), chromium(III), and chromium(VI) under batch conditions, as well as to examine the uptake of copper (II), lead (II), cadmium (II), and nickel (II) by silica immobilized cells of this strain of cyanobacteria under flow conditions. Experiments were conducted to find optimal binding $\mathrm{pH}$, time required for binding, and maximal capacity for binding of each metal. Further, tests were performed to investigate the ability to recover bound metals. Synechococcus sp. PCC 7942 biomass was immobilized in a silica polymer matrix, then tested for its ability to bind copper(II), lead(II), nickel(II), and cadmium(II). Additionally, a genetic investigation was performed to identify genes for class II metallothioneins in Synechococcus sp. PCC 7942 and seven other strains of cyanobacteria. 


\section{PROCEDURES}

\section{Cyanobacterial Collection}

Synechococcus sp. PCC 7942 was cultured under ideal conditions using liquid BG-11 media, which is commonly used for growing unicellular blue-green algae on plates (Allen, 1968). This media contains only trace amounts of metal ions and allows rich growth. The resulting biomass was then washed with sterile distilled water, freeze-dried (in a Labconco freeze-dryer), ground, and sieved to pass a 100-mesh screen. All experiments were conducted using biomass collected in this manner.

\section{pH Profile Studies for Metal Binding}

Batch laboratory methods were used for the $\mathrm{pH}$ studies. Samples (250-mg each) of dry, inactivated cyanobacterial biomass were washed twice with $0.01 \mathrm{M} \mathrm{HCl}$ to remove any debris or soluble biomolecules that might interact with metal ions. The samples were centrifuged and washings were collected to account for any biomass weight loss. The remainder of the procedure to determine the $\mathrm{pH}$ profile for copper(II) binding was similar to that reported previously (Gardea-Torresdey et al.,1996b). The same methods were used to study $\mathrm{pH}$ profiles for lead(II), nickel(II), cadmium(II), chromium(III), and chromium(VI). Concentrations for each metal tested were $0.1 \mathrm{mM}$.

\section{Time-dependency Studies for Metal Ion Binding}

Methods for time-dependency studies of metal binding were also performed under batch conditions. Samples $(250 \mathrm{mg})$ of the dry, inactivated cyanobacterial biomass were washed twice with $0.01 \mathrm{M} \mathrm{HCl}$. Samples were centrifuged and washings were collected, dried, and weighed to account for any biomass weight loss. The remainder of the procedure was analogous to that reported previously (Gardea-Torresdey et al.,1996b). Metal ion concentrations were $0.3 \mathrm{mM}$ for each metal while maintaining $\mathrm{pH} 5$ in $0.01 \mathrm{M}$ sodium acetate buffer. The time intervals tested were $5,10,15,30,60,90$, and $120 \mathrm{~min}$.

\section{Metal Binding Capacity Studies}

Samples (50 mg) of dry Synechococcus sp. PCC 7942 were washed twice with $0.01 \mathrm{M}$ $\mathrm{HCl}$ and washings were collected and weighed to determine biomass loss. The remainder of the procedure was similar to that reported regarding copper(II) binding by Mucor rouxii (Gardea- 
Torresdey et al., 1996c). Studies for the other metals were performed using this method, with concentrations of $0.3 \mathrm{mM}$ for each metal studied.

\section{Desorption of Adsorbed Metal}

In attempts to recover bound metal ions, samples of biomass laden to capacity (as described above) were exposed three times to $2 \mathrm{ml}$ of $0.1 \mathrm{M} \mathrm{HCl}$, reacted by agitation for 5 minute intervals and then centrifuged. After centrifugation, the supernatants were analyzed. All analysis for metals tested were performed by flame atomic absorption spectroscopy.

\section{Immobilization of Cyanobacterial Biomass}

The methodology of immobilization of Synechococcus sp. PCC 7942 within a polysilicate matrix was similar to that reported by Huei-Yang and Rayson (1993). A $2.5 \mathrm{~g}$ sample of biomass (100 mesh) was washed twice by vortexing the sample with deionized water and then centrifuged for $5 \mathrm{~min}$. at $3000 \mathrm{rpm}$ to remove solubles and debris. Next, $75 \mathrm{ml}$ of $5 \%$ sulfuric acid $\left(\mathrm{H}_{2} \mathrm{SO}_{4}\right)$ was mixed with enough $6 \%$ sodium silicate $\left(\mathrm{Na}_{2} \mathrm{SiO}_{3}\right)$ solution to raise the $\mathrm{pH}$ to 2.0. The remainder of the immobilization was performed following procedures previously reported (Gardea-Torresdey et al.,1996b).

\section{Column Experiments}

Using $3 \mathrm{ml}$ of immobilized Synechococcus sp. PCC 7942, a column $(0.9 \mathrm{~cm}$ i.d.x $4.7 \mathrm{~cm}$ height of biomass) was prepared having one bed volume equal to the volume of immobilized biomass inside the column $(3 \mathrm{ml})$. The column was washed with 24 bed volumes of $0.01 \mathrm{M}$ sodium acetate buffer at $\mathrm{pH} 5.0$ and effluent $\mathrm{pH}$ was monitored to ensure that the column was continuously at the optimal binding $\mathrm{pH}(\mathrm{pH}$ 5). A flow rate of $2 \mathrm{ml}$ per minute was used to pass 240 bed volumes of $6.3 \mathrm{mg} / \mathrm{L}$ copper(II), $5.8 \mathrm{mg} / \mathrm{L}$ nickel(II), $20.7 \mathrm{mg} / \mathrm{L}$ lead(II), $33.7 \mathrm{mg} / \mathrm{L}$ cadmium(II), $15.6 \mathrm{mg} / \mathrm{L}$ chromium(III), and $15.6 \mathrm{mg} / \mathrm{L}$ chromium(VI). Each metal solution contained 0.01 M sodium acetate at $\mathrm{pH} 5.0$ and was tested in triplicate. Each metal ion was tested independently.

\section{Recovery of Metal from the Column}

To remove the bound metal, $0.2 \mathrm{M} \mathrm{HCl}$ was passed through each column at a flow rate of $2 \mathrm{ml}$ per minute. Each effluent bed volume was collected and analyzed for metal content by flame atomic absorption spectroscopy. 


\section{Analytical Procedure}

All metal analyses were performed by flame atomic absorption spectroscopy (FAAS) using a Perkin Elmer model 3110 with deuterium background subtraction. Analytical wavelengths used for the various metals were as follows: copper, $327.4 \mathrm{~nm}$; lead, $217 \mathrm{~nm}$; nickel, $352.5 \mathrm{~nm}$; cadmium, $229 \mathrm{~nm}$; and chromium, $359.4 \mathrm{~nm}$. An impact bead was used to improve the sensitivity and samples were each read three times and the mean value computed. Calibrations were performed within a linear calibration range of each metal and the correlation coefficients for the calibration curves were 0.98 or better. Biomass-free controls of each of the metal solutions were analyzed to detect any possible metal precipitation or contamination. The difference between the initial metal concentration and the remaining concentration in supernatants and effluents was assumed to be taken up by the biomass.

\section{IDENTIFICATION OF CYANOBACTERIAL METALLOTHIONEIN GENES}

\section{Bacterial Strains and Culture Conditions}

Spirulina sp. ATCC 53843, Microcystis aeruginosa ATCC 22663, Anabaena flos aquae ATCC 22664, Nostoc sp. ATCC 29105, Fischerella Gomont ATCC 27929, Synechococcus sp. PCC 6714, and Synechococcus sp. PCC 7942 were each cultured in BG-11 for 2 weeks under constant flourescent light (50 micromole quanta $\left.\mathrm{m}^{-2} \mathrm{~s}^{-1}\right)$ first on a shaker (140 rpm) and later with air bubbling at $27^{\circ} \mathrm{C}$. Prochlorothrix hollandica was obtained from Dr. George Bullerjahn, (Bowling Green State University, Bowling Green, Ohio) and was grown in BG-11 with constant flourescent light (40 micromole quanta $\mathrm{m}^{-2} \mathrm{~s}^{-1}$ ) and air bubbling at $25^{\circ} \mathrm{C}$ for two weeks.

\section{Restriction Enzymes and DNA Markers}

The following enzymes were used in the restriction digestion analysis, HaeIII, Hinfl, MspI, RsaI, and TaqI. Restriction enzymes, Taq polymerase, oligonucleotide size markers, and agarose were purchased from New England BioLabs, Promega, \& GIBCO-BRL.

\section{Polymerase Chain Reaction}

Metallothionein (SmtA) locus amplification was performed using oligonucleotides described by Robinson et al.(1990), using standard protocols described in Ausubel and Seidman (1987). 


\section{Sequence Alignment of the Class II Metallothioneins}

PIMA sequence alignment was performed using the algorithms of Smith and Smith (1990, 1992).

\section{RESULTS AND DISCUSSION}

Previous screening experiments with Synechococcus sp. PCC 7942 revealed the effects of $\mathrm{pH}$ on the binding of copper(II), lead(II), and nickel(II) (Gardea-Torresdey et al.,1996a). Figure 1 shows the results of the $\mathrm{pH}$ profile for these three metals as well as for cadmium(II), chromium(III), and chromium(VI). It is evident that increased sorption of copper(II), nickel(II), cadmium(II), and chromium(III) was observed as the $\mathrm{pH}$ increased from 2 to 6 . On the other hand, Synechococcus sp. PCC 7942 bound lead over a wide $\mathrm{pH}$ range in a rather $\mathrm{pH}$-independent manner. The maximum binding observed was between $\mathrm{pH} 5$ and 6 . The percent metal bound was taken to be the difference between the control and the final concentration of metal in the supernatant. Previous studies showed that certain metal ions begin to precipitate out of solution once pH exceeds 6.0 (Gardea-Torresdey et al., 1996b). Therefore, maximum pH binding was taken as being $\mathrm{pH}$ 5. Further, the similar trends seen in copper(II), nickel(II), cadmium(II), and chromium(III) binding suggest that carboxyl groups play a role in the metal binding. The aciddissociation constants (pKa's) for carboxyl groups have been reported to be around 3-4 (Hunt, 1986; Segel, 1976). As pH increases, these groups become deprotonated and attract the positively charged metal ions.

Figure 2 represents the time-dependency results. As can be seen, lead(II), cadmium(II), and nickel(II) are bound immediately within the time required to mix the biomass and metal ions, without agitation, and quickly centrifuging. Copper(II) and chromium(III), on the other hand, required longer times to reach maximum adsorption.

Experiments were carried out to determine the metal binding capacities of the Synechococcus biomass at optimum binding $\mathrm{pH}$. Previous studies determined the capacity of Synechococcus sp. PCC 7942 to bind copper(II), lead(II), and nickel(II) (Gardea-Torresdey et al.,1996a). Using similar methods, binding capacities for cadmium(II), chromium(III), and chromium(VI) were also determined. Table 1 shows the results of the tests. The higher binding capacities for copper(II) and lead(II) can be observed. 
Experiments were also performed to determine the possibility of recovering metal ions bound by this biomass of particular strain of cyanobacteria. Previous studies showed that binding of copper(II) and nickel(II), and to a lesser extent lead(II), were favored at higher pH (GardeaTorresdey et al., 1996a). Our pH profile experiments also showed similar trends for cadmium(II) and chromium(III). This suggests that binding may be reversed by lowering the $\mathrm{pH}$. Therefore, as previously mentioned, $0.1 \mathrm{M} \mathrm{HCl}$ was used to strip the bound metal. Table 2 shows results of these experiments. While copper(II), lead(II), and nickel(II) had already shown efficient removal (Gardea-Torresdey et al., 1996a), cadmium(II) and chromium(III) showed a lesser percentage of removal. This indicates a need for usage of a stronger stripping agent, possibly EDTA, to recover cadmium(II) and chromium(III). Currently, experiments are being performed to find better stripping agents for cadmium(II) as well as for chromium(III).

Synechococcus showed good metal ion binding under batch conditions, but for biofiltration, Synechococcus sp. PCC 7942 would be most useful if it were capable of binding metal ions under flow conditions. By immobilizing the biomass in a silica polymer, the biomass could be packed into a column through which high flow rates could be achieved. Previous studies showed that optimal flow can be maintained if a polysilicate matrix support material were used to immobilize the biomass (Gardea-Torresdey et al., 1996b). Using this matrix, column experiments were conducted to study the effects of metal binding by the cyanobacterial biomass under flow conditions. Figure 3 represents the breakthrough curve for copper (II) (as copper (II) sulfate solution) passed through the column. The curve shows the amount of metal remaining after solutions at $\mathrm{pH} 5$ were passed through the column. After 100 bed volumes of copper solution were passed, only trace amounts of metal were detected in the effluent. Further, after 140 bed volumes, the column was nowhere near saturation. After elution with $0.2 \mathrm{M} \mathrm{HCl}$, the bound metal ions were recovered with most of the metal retrieved in bed volumes 2 to 6 . Figure 4 represents the curve showing this recovery.

Table 3 represents the results of average binding by the immobilized biomass to the various metals tested, as well as the average amount of recovery of each metal using $0.2 \mathrm{M} \mathrm{HCl}$. Excellent binding capacity was obtained for lead(II) ions. Further, copper(II) and lead(II) were almost completely stripped after treatment with $0.2 \mathrm{M} \mathrm{HCl}$, while lower recoveries were obtained 
for cadmium(II) and nickel(II). This is most likely due to different metal binding sites in this biomass.

Synechococcus could provide a recyclable system for adsorption of metal ions. Thus, using lead(II), the column was recycled for six cycles to test the column's ability to continue to remove lead(II) ions. Figure 5 shows the results of this experiment. As can be seen, the amount of lead(II) bound never dropped below $1000 \mathrm{mg} / \mathrm{L}$. The fluctuating pattern seen in the graph is likely due to channel formation in the column. These data suggest that a column containing immobilized Synechococcus sp. PCC 7942 could be used several times for removal of lead(II), and possibly other metal ions.

In order to possibly gain a better understanding of how metal binding may occur, polymerase chain reaction was used. This will demonstrate the presence of previously undescribed class II metallothionein genes in seven species of cyanobacteria. The best established example of this gene from Synechococcus sp. PCC 7942 yielded a PCR product of 187 base pairs. Products of this size were also obtained from the chromosomal DNA of five other cyanobacterial species, Synechocystis (2 species), Spirulina, Prochlorothriz, and Nostoc. Slightly larger products were obtained (220 base pairs) from the chromosomal DNA of Anabaena and Fischerella species. Restriction analysis, using four restriction enzymes which restrict DNA frequently, demonstrated that the amplified products were unique. These results, provided in Table 4, suggest that class II metallothionein genes are widespread among the cyanobacteria.

Class II metallothioneins may participate in the sequestration of toxic metal ions by the cyanobacteria. Previously, genes for these proteins were shown to be present only in three species of cyanobacteria, all of them from the genus Synechococcus (Turner and Robinson, 1995). We have demonstrated that genes for these proteins are widespread among the various genera and species of cyanobacteria. Our goal is to overexpress these proteins and to survey such engineered cyanobacteria for increased metal tolerance and for improved ability to sequester toxic metal ions. Derived amino acid sequences resulting from the further characterization of these genes will also drive experimentation aimed at elucidating the structure and function of these proteins. Figure 6 shows an amino acid alignment of representative class II metallothionein proteins from cyanobacteria and yeast. Amino acid sequence and composition is not strictly 
conserved in this protein class, but these proteins do show striking similarity in the positioning of amino acid functional groups. The number of thiol-containing cysteine residues (cysteine $=\mathrm{C}$ ) is somewhat less in the cyanobacterial proteins; however, their positions within the proteins are well conserved. It should also be noted that the positions of acidic residues, such as those containing carboxylates (aspartic acid = D, glutamic acid =E), as well as hydroxyl containing residues (serine $=\mathrm{S}$, threonine $=\mathrm{T}$, tyrosine $=\mathrm{Y}$ ) are also well conserved. These residues may also be involved in metal binding.

\section{CONCLUSION}

Batch laboratory experiments have shown that inactivated cells of Synechococcus $s p$. PCC 7942 are able to bind copper(II), lead(II), nickel(II), cadmium(II), and chromium(III) ions. This ability provided preliminary data showing the potential for the silica-immobilized biomass to be used as a biosorption resin for the removal and recovery of metal ions from contaminated waters. Every metal was sorbed and desorbed three times and lead(II) as many as six times. After one adsorption/desorption cycle, the column containing silica immobilized biomass was again capable of binding the metal ions well, or in appreciable levels. Future experiments will attempt to identify the metal ion-binding sites.

Metallothionein genes were shown to be present not only in Synechococcus sp. PCC 7942, but in seven other cyanobacterial strains. These proteins may act as defense mechanisms employed by the organism by binding metal ions intracellularly. Future experiments will attempt to overexpress these genes in engineered strains of Synechococcus sp. PCC 7942 with the idea that these strains would then be capable of binding more metal ions from solution.

\section{ACKNOWLEDGMENTS}

Dr. Gardea-Torresdey acknowledges the financial support from the NIH (grant \# GM08012-25). Javier Arenas acknowledges the support of the Howard Hughes Medical Institute. Dr. Webb acknowledges the support of The Research Centers in Minority Institutions Program of the NIH(Grant \# 3 G12 RR08124-0451). 


\section{REFERENCES}

Allen, M., 1968, Simple Conditions for Growth of Unicellular Blue-green Algae on Plates, J. Phycology, 4, pp. 1-4.

Ausubel, F.M. and R. Seidman, eds., 1987, Preparation and analysis of DNA. Current Protocols in Molecular Biology, 2.0.1-2.9.7.

Bender, J., J.P. Gould, Y. Vatcharapijarn, J.S. Young, and P. Phillips, 1994, Removal of Zinc and Manganese from Contaminated Water with Cyanobacteria Mats, Water Environ. Research, 66, 5, p. 679-683.

Bonilla, I., L. Bolanos, and P. Mateo, 1995, Interaction of Boron and Calcium in the cyanobacteria Anabaena and Synechococcus, Physiol. Plant., 94, pp. 31-36.

Borbely, G., G.S. Suranyi, and P. Kos, 1990, Stress Responses of Cyanobacteria and the Pleiotropic Effects of Light Deprivation, FEMS Microbiology Ecology. 74, pp. 141-152. Gardea-Torresdey, J.L., M.K. Becker-Hapak, J.M. Hosea, and D.W. Darnell, 1990, Effect of Chemical Modification of Algal Carboxyl Groups on Metal Ion Binding, Environ. Sci. Technol., 19, pp. 1372-1379.

Gardea-Torresdey, J.L., J.L. Arenas, R. Webb, K. Tiemann, and J. Gonzalez, 1996a, Uptake of Metal Ions from Solution by Inactivated Cells of Cyanobacteria. Proceedings for 1996 HSRC-WERC Joint Conference of the Environment, pp. 48-58.

Gardea-Torresdey, J.L., K.J. Tiemann, J.H. Gonzalez, I. Cano-Aguilera, J.A. Henning, and M.S. Townsend, 1996b, Ability of Silica-immobilized Medicago sativa (Alfalfa) to Remove Copper Ions from Solution. J. of Hazardous Materials. 48, pp.181-190.

Gardea-Torresdey, J.L., I. Cano-Agulera, K.J. Tiemann, and R. Webb, 1996c, Copper Adsorption by Inactivated Cells of Mucor rouxii: Effect of Esterification of Carboxyl groups, J. of Hazardous Materials, 48, pp. 171-180.

Gothalwal, R. and P.S. Bisen, 1993, Isolation and Physiological Characterization of Synechooccus cedrorum 1191 Strain Tolerant to Heavy Metals and Pesticides, Biology and Env. Sci., 6, pp. 187-194.

Huei-yang, D.K. and G.D. Rayson, 1993, Luminescence Study of $\mathrm{UO}_{2}{ }^{2+}$ Binding to Immobilized Datura innoxia Biomaterial, Appl. Spectroscopy, 47, pp. 44-51. 
Hunt, S., 1986, "Diversity of Biopolymer Structure and its Potential for Ion-binding Appliations," in Immobilization of Ions by Biosoption, H. Eccles, and S. Hunt, Eds., Ellis Horwood Limited, Chichester, England.

Kaplan, D., D. Christiaen, and S. M. Arad, 1987, Chelating Properties of Extracellular Polysaccharides from Chlorella spp., Appl. Environ. Microbiology, 53, 12, pp. 29532956.

Robinson, N.J., A. Gupta, A.P. Fordham-Skelton, R.R.D. Croy, B.A. Whitton, and J.W. Huckle,1990, Prokaryotic Metallothionein Gene Characterization and Expression: Chromosome Crawling by Ligand Mediated PCR. Proceedings of the Royal Society of London B, 242, pp. 241-247.

Segel, I.E., 1976, Biochemical Calculations, 2nd Edition, John Wiley and Sons Inc., New York. Silver, S. and G. Ji, 1994, Newer Systems for Bacterial Resistances to Toxic Heavy Metals. Environmental Health Perspectives, 102(3), pp. 107-113.

Silver, S. and G. Ji, 1994, Newer Systems for Bacterial Resistances to Toxic Heavy Metals, Environmental Health Perspectives, 102(3), pp. 107-113.

Smith, R.F. and T.F. Smith, 1990, Automatic Generation of Primary Sequence Patterns from Sets of Related Protein Sequences. PNAS, 87, pp. 118-122.

Smith, R.F. and T.F. Smith ,1992, Pattern-induced Multi-sequence Alignment (PIMA) Algorithm Employing Secondary Structure-dependent Gap Penalties for Comparative Protein Modelling. Protein Engineering. 5, pp. 35-41.

Slotton, D.G., C.R. Goldman, and A. Frank, 1989, Commercially Grown Spirulina Found to Contain Low Levels of Mercury and Lead, Nutrition Reports International, 40, 2, pp. 1165-1172.

Turner, J.S. and N.J. Robinson ,1995, Cyanobacterial Metallothioneins: Biochemistry and Molecular Genetics. J. of Industrial Microbiology. 14, pp. 119-125.

Van Eykelenburg, C., 1978, A Glucan from the Cell Wall of the Cyanobacterium. Antonie van Leeuwenhoek, 44, pp. 321-327.

Volesky, B. and Z.R. Holan., 1994, Biosorption of Lead and Nickel by Biomass of Marine Algae. Biotechnology and Bioengineering, 43, pp. 1001-1009. 
Volesky, B. and Z.R. Holan, 1995, Biosorption of Heavy Metals. Biotechnol. Prog., 11, 235250.

Volesky, B. and S. Schiewer, 1997, Ionic strength and Electrostatic Effects in Biosorption of Protons. Environmental Science and Technology, 31,7, pp. 1863-1871.

Zhang W. and V. Majidi, 1994, Monitoring the Cellular Response of Stichococcus bacillaris to Exposure of Several Different Metals Using in Vivo ${ }^{31} \mathrm{P}$ NMR and other Spectroscopic Techniques, Environ. Sci. Technol., 28, pp. 1577-1581.

Table 1. Metal Ion Binding Capacities of Inactivated Cells of Synechococcus sp. PCC 7942 biomass

\begin{tabular}{|c|c|}
\hline METAL TESTED & mg METAL/g BIOMASS \\
\hline COPPER (II) & $11.3 \pm 0.8$ \\
\hline LEAD (II) & $30.4 \pm 2.2$ \\
\hline NICKEL (II) & $3.2 \pm 0.7$ \\
\hline CADMIUM (II) & $7.2 \pm 2.1$ \\
\hline CHROMIUM (III) & $5.4 \pm 3.8$ \\
\hline CHROMIUM (VI) & $0.8 \pm 1.0$ \\
\hline
\end{tabular}

Note: Each datum represents the mean of three replicates. Each experiment was performed at $\mathrm{pH}$ 5, and a 95\% confidence interval was used to determine error. 
Table 2. Percent of Metal Ion Recovery from Inactivated Cells of Synechococcus sp. PCC 7942 Biomass After Treatment with 0.1 M HCL

\begin{tabular}{|c|c|}
\hline METAL TESTED & \% RECOVERED \\
\hline COPPER (II) & $98 \pm 2.5$ \\
\hline LEAD (II) & $99 \pm 3.6$ \\
\hline NICKEL (II) & $99 \pm 2.2$ \\
\hline CADMIUM (II) & $57 \pm 5.3$ \\
\hline CHROMIUM (III) & $52 \pm 5.6$ \\
\hline CHROMIUM (VI) & 0 \\
\hline
\end{tabular}

Note: Data represent the mean of three replicates, and a 95\% confidence interval was used to determine error.

Table 3. Average Amount of Metal Ion Bound by Silica Immobilized Biomass as well as the Percent Recovery after Treatment with $0.2 \mathrm{M} \mathrm{HCl}$

\begin{tabular}{|c|c|c|}
\hline & AVG. mg/L BOUND & AVG. \% RECOVERY \\
\hline COPPER (II) & $143 \pm 167.1$ & $97 \pm 10.3$ \\
\hline LEAD (II) & $1456 \pm 325.2$ & $99 \pm 9.2$ \\
\hline NICKEL (II) & $142 \pm 57.6$ & $42 \pm 3.3$ \\
\hline CADMIUM (II) & $529 \pm 146.4$ & $79 \pm 20.0$ \\
\hline
\end{tabular}

Note: Data represent results of three cycles performed. One cycle consisted of 240 bed volumes collected ( $3 \mathrm{ml}$ bed volume) with $2 \mathrm{ml}$ per min. flow rate. Influent metal concentrations were 0.1 $\mathrm{mM}$. Column dimensions were $0.9 \mathrm{~cm}$ i.d. X $14 \mathrm{~cm}$ height. The biomass was packed up to 4.7 $\mathrm{cm}$ in height. A $95 \%$ confidence interval was used to determine error. 
Table 4. Polymerase Chain Reaction (PCR) Product and Restriction Digestion Product Sizes (base pairs) Obtained for SmtA Genes (metallothionein) from DNA Isolated from Cyanobacterial Species.

\begin{tabular}{|c|c|c|c|c|c|}
\hline $\begin{array}{c}\text { Cyanobacterial } \\
\text { Species }\end{array}$ & $\begin{array}{c}\text { smtA PCR } \\
\text { products }\end{array}$ & HaeIII & MspI & RsaI & TaqI \\
\hline $\begin{array}{c}\text { Anabaena } \\
\text { ATCC } 22664\end{array}$ & 220 & ND & $\begin{array}{c}160 \\
43 \\
\mathrm{U}=17 \\
\end{array}$ & ND & ND \\
\hline $\begin{array}{c}\text { Fischerella } \\
\text { ATCC } 27929\end{array}$ & 20 & ND & $\begin{array}{c}170 \\
45 \\
\mathrm{U}=5\end{array}$ & ND & ND \\
\hline $\begin{array}{l}\text { Synechocystis } \\
\text { ATCC } 22663\end{array}$ & 187 & $\begin{array}{c}125 \\
50 \\
\mathrm{U}=12 \\
\end{array}$ & $\begin{array}{c}134 \\
17 \\
\mathrm{U}=36 \\
\end{array}$ & $\begin{array}{c}95 \\
\mathrm{U}=92 \\
\end{array}$ & $\begin{array}{r}100 \\
\mathrm{U}=87 \\
\end{array}$ \\
\hline $\begin{array}{c}\text { Nostoc ATCC } \\
29105\end{array}$ & 187 & $\begin{array}{c}105 \\
15 \\
\mathrm{U}=67\end{array}$ & $\begin{array}{c}100 \\
10 \\
\mathrm{U}=77\end{array}$ & $\begin{array}{c}90 \\
\mathrm{U}=97\end{array}$ & $\begin{array}{c}97 \\
\mathrm{U}=90 \\
\end{array}$ \\
\hline $\begin{array}{l}\text { Prochlorothrix } \\
\text { hollandica }\end{array}$ & 187 & $\begin{array}{c}105 \\
60 \\
\mathrm{U}=22 \\
\end{array}$ & $\begin{array}{c}105 \\
20 \\
\mathrm{U}=62 \\
\end{array}$ & $\begin{array}{c}80 \\
\mathrm{U}=107\end{array}$ & $\begin{array}{c}97 \\
\mathrm{U}=90 \\
\end{array}$ \\
\hline $\begin{array}{c}\text { Spirulina } \\
\text { ATCC } 53843\end{array}$ & 187 & $\begin{array}{c}106 \\
25 \\
\mathrm{U}=56\end{array}$ & $\begin{array}{c}120 \\
20 \\
\mathrm{U}=47\end{array}$ & $\begin{array}{c}90 \\
\mathrm{U}=97\end{array}$ & $\begin{array}{c}90 \\
\mathrm{U}=97\end{array}$ \\
\hline $\begin{array}{l}\text { Synechocystis } \\
\text { PCC } 6714\end{array}$ & 187 & $\begin{array}{c}128 \\
\mathrm{U}=59 \\
\end{array}$ & $\begin{array}{r}128 \\
\mathrm{U}=59 \\
\end{array}$ & $\begin{array}{c}90 \\
\mathrm{U}=97\end{array}$ & $\begin{array}{c}95 \\
\mathrm{U}=92 \\
\end{array}$ \\
\hline $\begin{array}{l}\text { Synechococcus } \\
\text { PCC } 7942\end{array}$ & 187 & $\begin{array}{c}112 \\
\mathrm{U}=75\end{array}$ & $\begin{array}{c}112 \\
\mathrm{U}=75\end{array}$ & $\begin{array}{c}90 \\
\mathrm{U}=97\end{array}$ & $\begin{array}{r}100 \\
\mathrm{U}=87\end{array}$ \\
\hline
\end{tabular}

Note: PCR products were digested with HaeIII, MspI, RsaI, and TaqI. PCR products and restriction digestion fragments are given in base pairs. U=Fragment sizes which could not be resolved and $\mathrm{ND}=$ no digestion. 


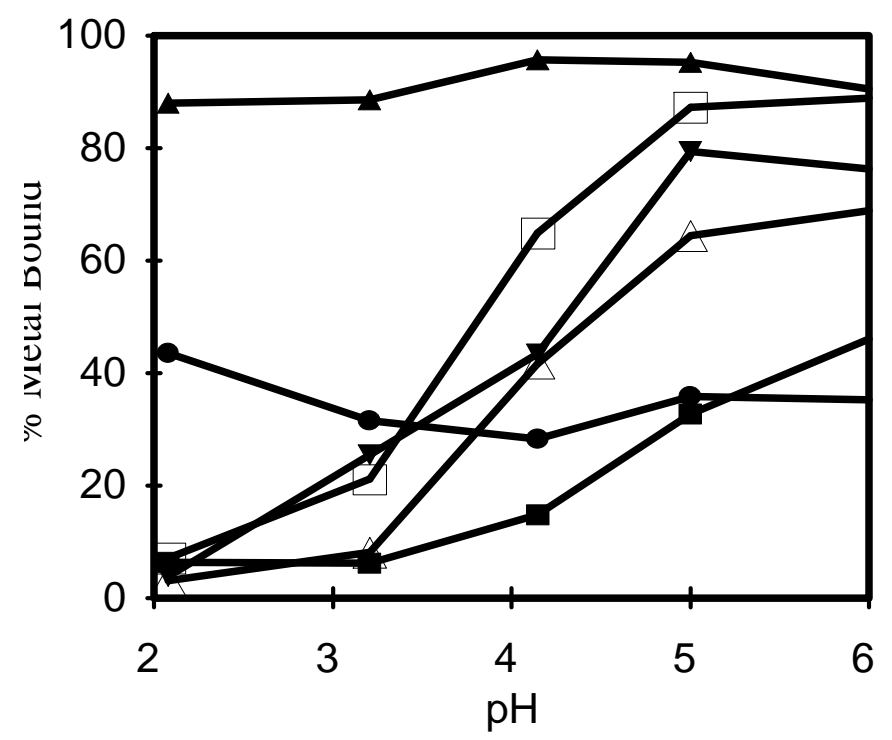

Figure 1. Percent Copper $(\square), \operatorname{Lead}(\mathbf{\Delta}), \operatorname{Nickel}(\Delta), \operatorname{Cadmium}(\boldsymbol{\square})$, Chromium (III)( $\quad$ ), and Chromium $(\mathrm{VI})(\bullet)$ removed from Solution as a Function of $\mathrm{pH}$ by Inactivated Cells of Synechococcus sp. PCC 7942. Biomass $(5 \mathrm{mg} / \mathrm{ml})$ was reacted for 1 hour at the appropriate $\mathrm{pH}$ with $0.1 \mathrm{mM}$ copper(II). The same procedure was repeated with $0.1 \mathrm{mM}$ lead(II), nickel(II), cadmium(II), chromium(III), and chromium(VI).

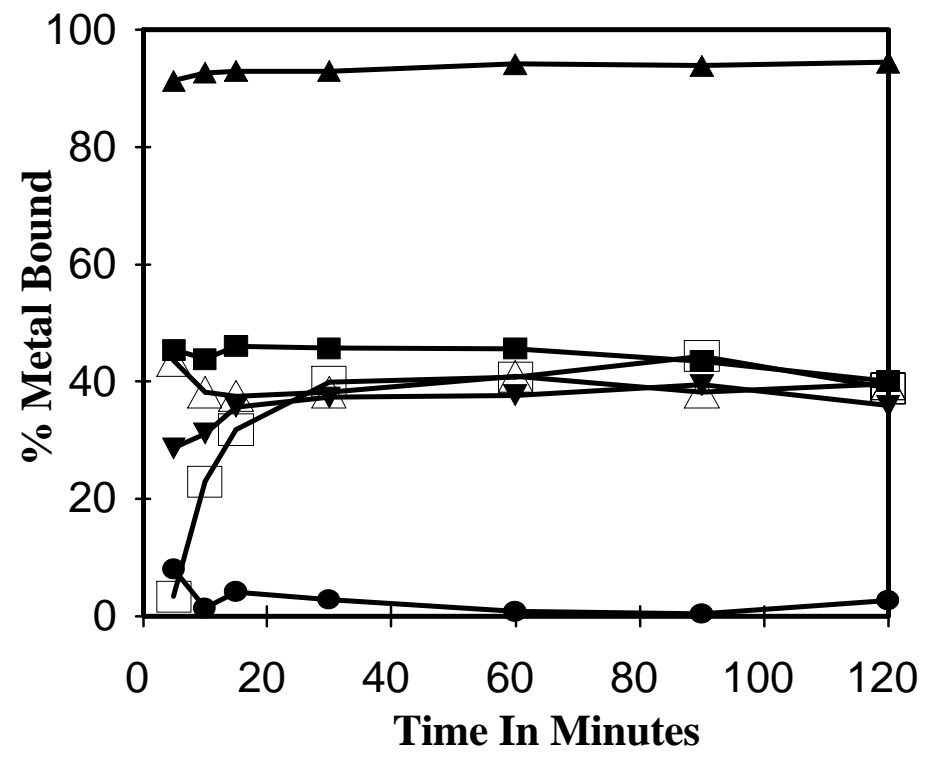

Figure 2. Percent Copper ( $\square), \operatorname{Lead}(\boldsymbol{\Delta}), \operatorname{Nickel}(\Delta), \operatorname{Cadmium}(\boldsymbol{\square})$, Chromium (III) ( ), and Chromium (VI)(•) Removed frome Solution at Different Reaction Times by Inactivated Cells of Synechococcus sp. PCC 7942. Biomass $(5 \mathrm{mg} / \mathrm{ml})$ was reacted for appropriate times with 0.3 $\mathrm{mM}$ copper(II) in $0.01 \mathrm{M}$ sodium acetate buffer at $\mathrm{pH}$ 5.0. The same procedure was repeated with $0.3 \mathrm{mM}$ lead(II), nickel(II), cadmium(II), chromium(III), and chromium(VI). 


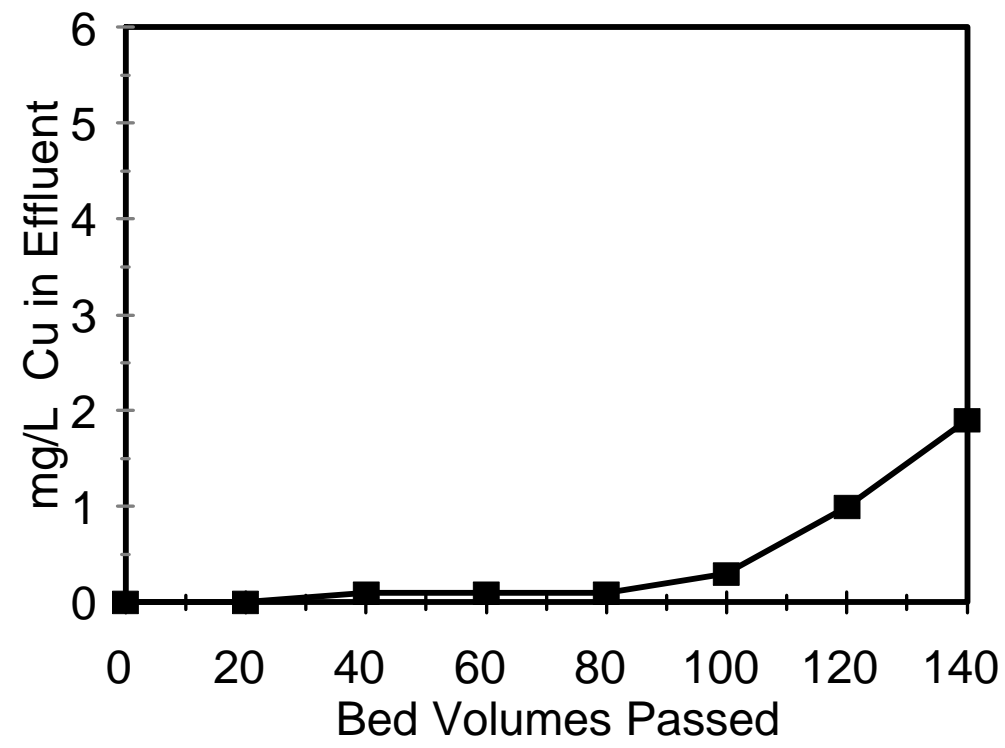

Figure 3. Breakthrough Curve for Copper Binding Under Flow Conditions. A solution of 6.3 $\mathrm{mg} / \mathrm{L}$ copper(II) in $0.01 \mathrm{M}$ sodium acetate at $\mathrm{pH} 5$ was passed through a column containing immobilized biomass ( $3 \mathrm{ml}$ bed volume). The flow rate was at $2 \mathrm{ml}$ per min.

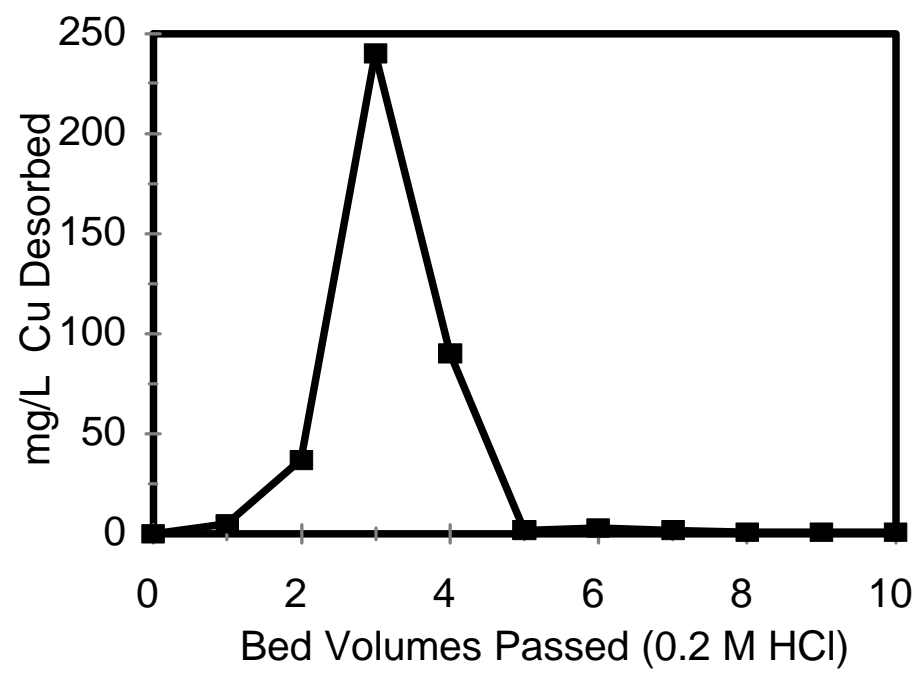

Figure 4. Desorption Curve for Copper(II) After Binding Under Flow Conditions. Using the same column used to gather data for Figure 4, ten bed volumes of $0.2 \mathrm{M} \mathrm{HCl}$ were passed at a flow rate of $2 \mathrm{ml}$ per min. 


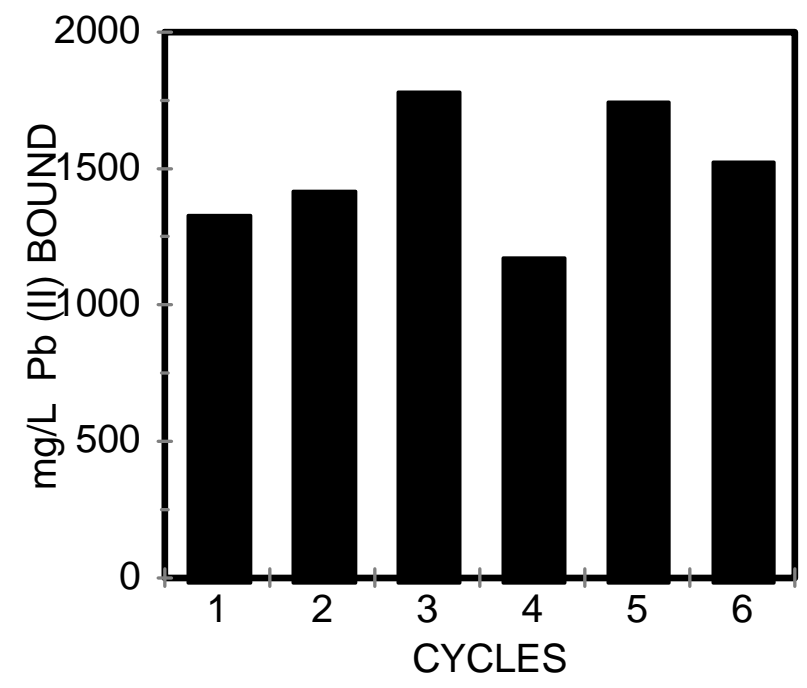

Figure 5. Recycling of Lead(II) Binding Under Flow Conditions. A solution of $22.7 \mathrm{mg} / \mathrm{L}$ lead (II) in $0.01 \mathrm{M}$ sodium acetate at $\mathrm{pH} 5$ was passed through a column containing immobilized biomass ( $3 \mathrm{ml}$ bed volume). The flow rate was $2 \mathrm{ml}$ per min. and six cycles were run collecting 240 bed volumes per cycle.

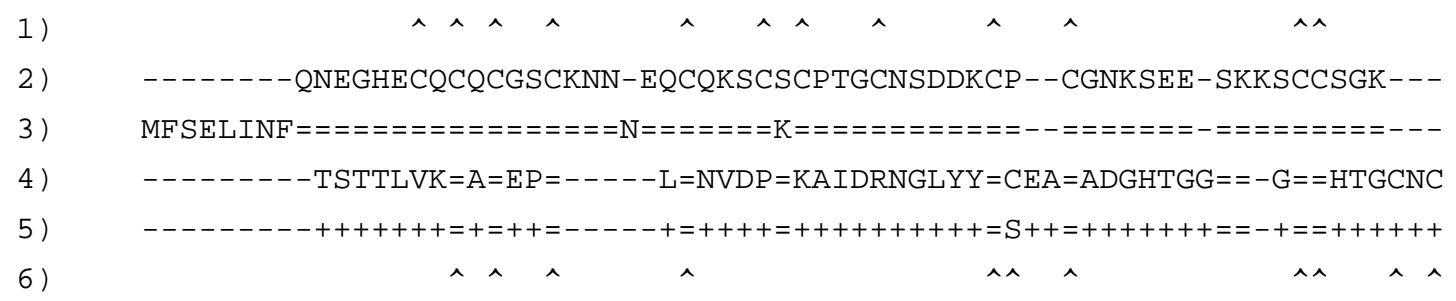

Figure 6. Amino Acid Sequence Alignment of Representative Class II Metallothioneins. Metallothinein protein sequences are presented using the IUPAC single letter code. Dashed lines (-) represent sequence gaps inserted to improve the alignment. Lines 2 and 3 are the sequences of Saccharomyces cerevisiae class II metallothineins copies one and two, respectively. Lines 3 and 4 are representations of the Synechococcus sp. PCC 7942 and PCC 6301 sequences, respectively. Equals signs (=) represent positions with amino acid identity to the $\mathrm{S}$. cerevisiae class II metallothionein copy one sequence. Plus signs represent positions in the Synechococcus sp. PCC 6301 sequence with amino acid identity with the Synechococcus sp. PCC 7942 sequence. Carets in lines 1 and 6 highlight the positions of conserved, thiol-containing, cysteine residues. 